\title{
SWOT-assessment of recycling materials for cheap explosives used in the development of fields in the Russian Arctic zone
}

\author{
Alexandre Frantov* \\ Institute of Comprehensive Exploitation of Mineral Resources Russian Academy of Sciences,111020, \\ Moscow, Russia
}

\begin{abstract}
The recycling potential is being actualized due to the trends in the production and use of powder and liquid combustible materials from the waste of a mining enterprise in the production cycle of mining, enrichment and processing (polymer packaging and containers of explosives, large tires and rubber products during the operation of mining vehicles, coal powder and coke breeze during enrichment and coking of coal, waste oil products during the operation of vehicles and mechanization equipment). In the material under consideration, a SWOT analysis of the possibility of using the recycling technology of materials in the manufacture of the simplest explosives in the northern and arctic regions of Russia is carried out, including consideration of geological, natural, climatic, economicgeographical, environmental, technological and technical aspects. On the basis of the presented detailing of the indicators of the considered aspects of the SWOT analysis, their role is shown and the value is highlighted when using the technology of recycling materials for the simplest explosives in the development of medium and small deposits. The possibility of obtaining recycled material used for the manufacture of the simplest explosives at mining enterprises from alternative manufacturers is shown.
\end{abstract}

\section{Introduction}

Improving blasting technologies at mining enterprises is the key to the success of the entire production and technological cycle of mining. This tendency is clearly manifested for the northern and arctic regions of Russia, where the interrelationships of the "geologyenvironmental protection-technology" system are especially prominent. Mining waste waste petroleum products (WPP), large-size tires (LST) of mining dump trucks, industrial rubber goods (IRG), plastic packaging materials (PPM), coal dust fractions (CD) are a serious factor of environmental pollution. The development and improvement of new technical solutions, namely the recycling of materials in blasting technology, will help expand the potential of medium and small deposits in the northern and arctic regions of Russia, increase

\footnotetext{
* Corresponding author: aef1948@gmail.com
} 
the profitability of enterprises, especially those developed in difficult natural, climatic and mining conditions.

The northern and arctic regions of Russia have vast mineral resources, so according to the data [1], reserves are concentrated in the Arctic zone and adjacent territories (\% of allRussian): gold - 40, nickel, copper, antimony, cobalt, tin, tungsten, mercury, apatite, phlogopite - 50-90, chromium and manganese - 90, platinum metals - 99, indigenous diamonds and vermiculite - 100. Along with super-large and giant deposits in the region, there are medium and small-scale alluvial deposits of gold, platinum group metals, rare metals and titanium, diamonds, as well as primary deposits of gold, tin, etc. [2; 3; 4].

\section{Research methodology}

To assess the effectiveness of the technology of recycling materials in the manufacture of explosives in the development of deposits in the considered region of Russia, an analysis was carried out using the SWOT method. The abbreviation SWOT in English means [5]: “... S Strengths - strengths, advantages; W - Weaknesses - weaknesses; O - Opportunities opportunities, chances, prospects; T - Threats - threats, dangers, risks ... ". It is advisable to place the categorical parameters of the SWOT analysis in the matrix-quadrant, highlighting the relevant aspects and indicators. In accordance with the accepted methodological approach of SWOT analysis, the "external environment" is highlighted, in which, for our case, aspects are investigated - geological, natural, climatic, economic-geographical and ecological, and technological and technical aspects are investigated in the allocated "internal resources". For all the identified aspects of the analysis, they are detailed by indicators.

The choice of the aspects and indicators studied by the SWOT method was determined on the basis of an analysis of materials for the placement of natural resources in the northern and arctic regions of Russia, the established restrictions on geological, natural, climatic, geographic and economic factors [6 - 9]. The technological approach to the implementation of the use of recycled materials in the manufacture of explosives is formed on the basis of the "geotechnological paradigm for the development of integrated subsoil development in the Arctic zone of Russia" [10], within which the development of medium and small deposits is being developed taking into account natural, climatic, infrastructural (significant isolation, low energy supply, high level of construction costs, lack of a road network, etc.) and other conditions. The correctness of this conceptual model is confirmed and embodied in the main provisions of the "Strategy for the spatial development of the Russian Federation for the period up to 2025" [11], adopted in 2019 by the Government of the Russian Federation, aimed at the formation and development of mineral resource complexes and a number of other government documents - "Fundamentals of the state policy of regional development of the Russian Federation for the period up to 2025" [12] etc. In this context, the recycling of materials is a driving force for improving the structure and composition of energy-intensive materials, tools and methods for managing rock destruction. The subject of recycling of liquid and solid materials used in the formulation of the simplest explosives are:

- waste oil products - used motor and hydraulic oils, oil flushing liquids, as well as mixtures of oil and oil products;

- fuel mixture - a mixture of waste and primary petroleum products. Primary petroleum products are used to condition the viscosity properties of the mixture;

- pyrolysis oil is a multicomponent mixture of hydrocarbons, which is a dark liquid, consisting mainly of unsaturated and aromatic hydrocarbons. Formed by thermal decomposition of rubber without oxygen;

- crumb rubber - an aggregate of crushed rubber particles of different dispersion and various shapes, which basically retains the molecular structure and elastomeric properties of the original rubber; 
- coal powder - free-flowing material in the form of small particles formed during the extraction, enrichment or processing of coal;

- coke breeze - a non-volatile carbonaceous residue obtained in the coking technology by calcining coals at high temperatures in closed vessels;

- polypropylene plastic crumb - loose material in the form of small particles formed by crushing secondary polypropylene during its processing by crushing and grinding;

- plastic crumb polyethylene - loose material in the form of small particles, formed by crushing secondary polyethylene during its processing by crushing and grinding;

- carbon black - free-flowing carbon material obtained during the processing of automobile tires by pyrolysis;

- low-quality graphene is a free-flowing carbon material obtained during the processing of automobile tires by the "flash" technology.

The main means used in the destruction of rocks in mining technology are explosives, on the properties of which the choice of equipment and technology for drilling and blasting operations largely depends. The development of innovative blasting technologies used in the northern and arctic regions of Russia is based on knowledge of the properties of the components used in the manufacture of the simplest explosives. Modern approaches to the formation of the properties of the simplest explosives using materials obtained by recycling technology are determined when using $[11 ; 12 ; 13]$ :

- $\quad$ oil products - reducing the cost of the cheap explosives, solving environmental problems.

- pyrolysis oil, frost-resistant fuel oil, arctic fuel oil - reducing the cost of the simplest explosives, solving environmental problems.

- coal powder, coke breeze, rubber crumb - reducing the cost of the simplest explosives, improving the adhesion of fuel and oxidizer, retention capacity, increasing heat, solving environmental problems.

- carbon black, low-quality graphene, plastic chips - reducing the cost of the simplest explosives, improving the adhesion of fuel and oxidizer, retention capacity, increasing heat, solving environmental problems.

\section{Research results}

A systematic analysis of the raw material potential of minerals in the northern and arctic regions of Russia [1; 6-9], peculiarities of placement of small and very small ore and placer deposits [3; 4], the development of innovative technologies for blasting operations using the simplest explosives [13-15] made it possible to present the strengths and weaknesses of the technology for recycling materials for use in explosive technology in the development of deposits in the northern and arctic regions of Russia (Table 1).

Table 1: Analysis based on the SWOT method of strengths and weaknesses in the use of materials recycling technology in the manufacture of the simplest explosives in the development of medium and small deposits in the northern and arctic regions of Russia.

\begin{tabular}{|l|l|}
\hline$(+)$ S - list of benefits & $(-)$ W - list of shortcomings \\
\hline Geological aspects: & Geological aspects: \\
- development of minor, small and very small & - small reserves of small and very small deposits; \\
deposits; & - insufficient reliability of the calculation of \\
- involvement in the development of off-balance & reserves; \\
reserves; & - difficult mining and hydrogeological operating \\
- development of ore and placer deposits. & conditions. \\
Technological aspects: & Natural aspects : \\
- no need to build complex and expensive & - negative temperature of the rock mass; \\
factories for the production of explosives; & \\
\hline
\end{tabular}


- collection, storage, processing and use of WPP, LST, IRG, PPM, CD.

Technical aspects:

- the use of relatively inexpensive mixingcharging and transport machines;

- use instead of liquid petroleum products as combustible components of explosives materials obtained by WPP, LST, IRG, PPM, CD recycling;

- reduction of the amount of petroleum products in the formulation of explosives;

- a wide range of physical and mechanical properties of blasted rocks using explosives based on materials obtained by WPP, LST, IRG, PPM, CD recycling.

\section{Environmental aspects:}

reducing the load on the natural environment due to the involvement of WPP, LST, IRG, PPM, CD materials in the production turnover.

\section{(+) $\mathrm{O}$ - list of prospects}

\section{Geological aspects:}

the possibility of developing previously developed medium and small deposits with additionally explored reserves;

high quality of ores and recoverability of metal.

Economical and geographic aspects:

short terms of commissioning of small fields.

Technological aspects:

expanding the list of materials used in recycling technology in the production of explosives.

Technical aspects:

Improvement of explosive, technological properties of explosives, based on materials obtained in recycling technology.
- seasonality of work during the mining of placers.

Climatic aspects:

- harsh climate with a long period of negative temperatures.

Economical and geographic aspects:

- remoteness and inaccessibility of deposits;

underdevelopment of engineering infrastructure (low energy supply, high level of construction costs, etc.);

- the need to attract significant financial resources for the development of mining facilities.

Technological aspects:

- availability of equipment for processing WPP, LST, IRG, PPM, CD and other materials for blasting technology.

Technical aspects:

- the use of mixing and charging machines capable of producing explosives with powder fuels;

- conditioning of the viscosity-temperature properties of liquid combustible additives when using explosives at a negative ambient temperature.

\section{(-) $\mathbf{T}$ - list of risks}

Economical and geographic aspects:

- insufficient development of the main transport routes (sea, junction automobile and railways); - the existing territorial disunity of mining and processing enterprises of certain types.

\section{Technological aspects:}

- imperfection or lack of technology for obtaining marketable products in the extraction of minerals.

\section{Technical aspects:}

- lack of transport accessibility of the network of alternative producers of WPP, LST, IRG, PPM, $\mathrm{CD}$ processing materials.

\section{Discussion of results}

In the category of "advantages", the key position is geological aspects characterizing the mineral resource potential, scale, state of reserves and the type of deposits where materials recycling technologies are used in the manufacture of explosives. The second aspect meets the demands of mining enterprises to introduce innovative, cost-effective technologies for the production of explosives. The technical aspects of "advantages" are of no less priority importance, including four points and showing directions for improving the technology for the manufacture of explosives, improving the formulations of explosives (due to materials obtained by the WPP, LST, IRG, PPM, CD recycling technology) and increasing the 
efficiency of blasting operations when applying them. The environmental aspect reflects the competitive advantages of the offer due to the involvement of these materials in the production turnover. One of the most important factors in the category of "prospects" for geological aspects is the possibility of reworking previously operated medium and small deposits with confirmation of an increase in reserves, high quality of ores, and metal recoverability. The pivotal factor of the economic and geographical aspect is the short terms of involving small deposits in operation, which ensures a quick return on investment. Technological and technical aspects of the implementation of "prospects" are associated with the introduction of innovations to expand the list of materials used in recycling technology, improve the explosive and technological properties of explosives, based on new materials obtained in recycling technology.

In the category of "disadvantages" indicators include climatic, natural and economicgeographical aspects, which have a significant impact on the economic, technological and technical performance indicators of a mining enterprise with the use of recycling materials for use in blasting operations. Geological, natural, climatic aspects characterize the complicating conditions associated with the provision of reserves and confirmation of their quality, the presence of permafrost, the production of open-pit mining, the implementation of technological processes for the development of placer deposits. Economic and geographical aspects primarily focus on understanding the general economic development of the region (transport, engineering infrastructure) and investment policy directions, and technological and technical aspects form an understanding of the importance of the availability of production equipment for processing secondary materials for blasting technology at a mining enterprise or the possibility of obtaining processing materials from alternative manufacturers, as well as directly for blasting technology - this is the availability of mixing and charging equipment for working with powder fuels.

As alternative manufacturers of recycled materials used for the manufacture of the simplest explosives at mining enterprises, we present a list of Russian manufacturers, for example, coke breeze (Table 2), indicating their location in the Siberian region, selling price, the presence of branches of the manufacturing enterprise and their location.

Table 2. Producers of coke breeze in the Siberian region.

\begin{tabular}{|l|c|c|}
\hline \multicolumn{1}{|c|}{ Manufacturer } & Price, RUR th/t & Note \\
\hline PJSC Koks, Kemerovo & On request & \\
\hline Altai-koks JSC, Zarinsk, Altai Territory & On request & $\begin{array}{c}\text { branch in } \\
\text { Khabarovsk }\end{array}$ \\
\hline BVB-Alliance, Yekaterinburg & 15.8 & $\begin{array}{c}\text { branch in } \\
\text { Khabarovsk }\end{array}$ \\
\hline PO "Pipe solution", Novosibirsk & 15.8 & \\
\hline Company "Promtorg" N, Novokuznetsk & 1.5 & \\
\hline TC "Resource", Novosibirsk & 9.5 & \\
\hline
\end{tabular}

\section{Conclusion}

The presented SWOT analysis of the technology of recycling materials in the manufacture of explosives in the development of medium and small deposits in the northern and arctic regions of Russia makes it possible to determine the strategic directions of application of the technology under consideration.

As we can see from the data in Table 2, the presence of a sufficiently large market for alternative producers of coke breeze allows mining enterprises to stabilize the risks of reducing their own production of recycled materials for the manufacture of simple 
explosives. A similar situation exists for other recycling materials: waste oil products of the WEO or WIO groups, coal powder, rubber crumb.

The SWOT analysis technique, along with good data structuring, has some static indicators and a certain subjectivity. To overcome the aforementioned shortcomings, the methodology allows for the possibility of ranking indicators using a point assessment, as well as attracting the collective opinion of experts, but these aspects are not considered in this work.

\section{References}

1. D.A. Dodin, V.D. Kaminskij, K.K. Zoloev, V.A. Koroteev, Litosfera, 6, 3 (2010)

2. Poleznye iskopaemye v Arktike. Oznakomlenie (Skipnes Kommunikashon, 1-oe izdanie, 2016)

3. A.V. Lalomov, A.A. Bochneva, R.M. CHefranov, A.V. CHefranova, Arktika: ekologiya i ekonomika, 2(18), 66 (2015)

4. G.V. Sekisov, E.V. Nigaj, A.A. Sobolev, Gornyj informacionno-analiticheskij byulleten' (nauchno-tekhnicheskij zhurnal), 9(12), 66 (2007)

5. SWOT-analiz: primery, voprosy, matrica reshenij, plan meropriyatij, https://genuspeharu.turbopages.org/genuspeha.ru/s/swot-analiz-primeri/

6. D.A. Dodin, V.L. Ivanov, Razvedka i ohrana nedr, 12, 17 (2000)

7. N.L. Dobrecov, N.P. Pohilenko, Geologiya i geofizika, 511, 126 (2010)

8. N.A. Kondratov, Geograficheskij vestnik, 3(38), 35 (2016)

9. YU.G. Safonov, Geologiya i geofizika, 51(1), 142 (2010)

10. K.N. Trubeckoj, YU.P. Galchenko, G.V. Kalabin, A.N. Proshlyakov, Arktika: ekologiya i ekonomika, 3(19), 54 (2015)

11. Strategiya prostranstvennogo razvitiya Rossijskoj Federacii na period do 2025 goda. Utv. Rasporyazheniem Pravitel'stva Rossijskoj Federacii ot 13 fevralya 2019 g. № 207 r.

12. Osnovy gosudarstvennoj politiki regional'nogo razvitiya Rossijskoj Federacii na period do 2025 goda. Ukaz Prezidenta RF ot 16.01.2017 N 13.

13. S.D. Viktorov, A.E. Frantov, P.I. Opanasenko, I.B. Strogij, I.F. ZHarikov, I.N. Lapikov, Ugol', 11, 17 (2020)

14. S.D. Viktorov, A.E. Frantov, I.N. Lapikov, R.A. Rahmanov, YU.I. Suvorov, V.H. Kantor, V.YU. Fadeev, V.A. Tihonov, V.V. Rad'kov, V.V. ZHulikov, Vzryvnoe delo, 129(86), 118 (2020)

15. S.D. Viktorov, A.E. Frantov, I.N. Lapikov, R.YA. Mingazov, Inzhenernaya fizika, 8, 25 (2020) 